\title{
Bronchial Epithelial Hyperplasia
}

National Cancer Institute

\section{Source}

National Cancer Institute. Bronchial Epithelial Hyperplasia. NCI Thesaurus. Code C97079.

Hyperplasia of the bronchial epithelial cells. It is often associated with squamous

metaplasia. 